\title{
THE USE OF DOMINO CARDS AS TEACHING MEDIA OF DESCRIPTIVE TEXT AT SMP N 6 WONOGIRI
}

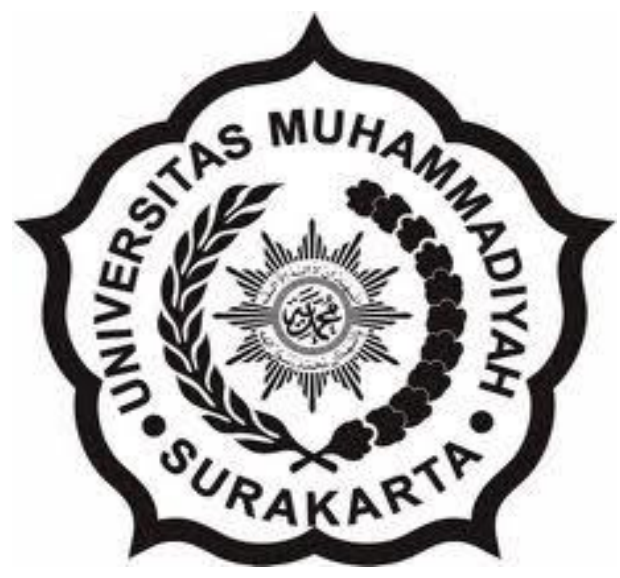

Submitted as a Partial Fulfillment of the Requirements for Getting Bachelor Degree in Department of English Education

By:

BYANTARA CANTAKA MAYESTIENDRA AJI

A320160096

\author{
DEPARTMENT OF ENGLISH EDUCATION \\ SCHOOL OF TEACHER TRAINING AND EDUCATION \\ MUHAMMADIYAH UNIVERSITY OF SURAKARTA \\ 2020
}


APPROVAL

\section{THE USE OF DOMINO CARDS AS TEACHING MEDIA OF DESCRIPTIVE TEXT AT SMP N 6 WONOGIRI}

\section{PUBLICATION ARTICLE}

Proposed by:

\section{BYANTARA CANTAKA MAYESTIENDRA AJI}

A320160096

\section{Approved to be examined by Consultant School of Teacher Training and Education} Muhammadiyah University of Surakarta

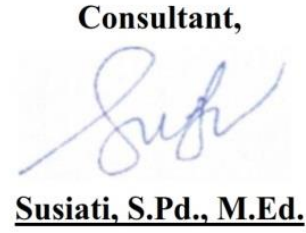


ACCEPTANCE

THE USE OF DOMINO CARDS AS TEACHING MEDIA OF DESCRIPTIVE TEXT AT SMP N 6 WONOGIRI

by :

\section{BYANTARA CANTAKA MAYESTIENDRA AJI}

A320160096

Accepted by the Board of Examiner School of Teacher Training and Education

Universitas Muhammadiyah Surakarta

on 17 December, 2020

Team of Examiner :

1. Susiati,S.Pd., M.Ed

(Chair Person)

2. Koesoemo Ratih, Ph.D (Member I)

3. Aryati Prasetyarini, M.Pd (Member II)

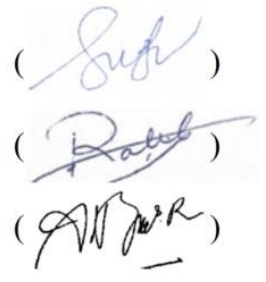

Dean,

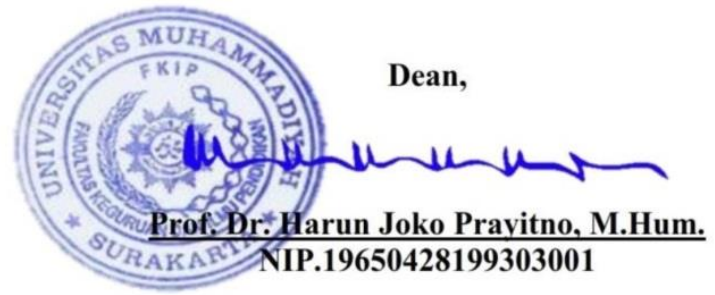




\section{PRONOUNCEMENT}

Herewith, the writer testifies that this publicaticon article there is no plagiarism of the research which has been made before to complete the bachelor degree in the university and as long as the witer knows that there is no work or opinion which ever been published or composed by the other writer or researcher, except those whic the writing referred in the manuscript and mentioned in the bibliography.

However, if it proves that there are some untrue statements here, the writer will be fully responsible.

Surakarta, 17 December 2020

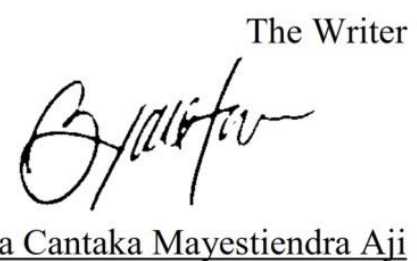

A320160096 


\title{
THE USE OF DOMINO CARDS AS TEACHING MEDIA OF DESCRIPTIVE TEXT AT SMP N 6 WONOGIRI
}

\begin{abstract}
Abstrak
Penelitian ini bertujuan untuk mengetahui proses pembelajaran teks deskriptif dengan menggunakan kartu domino dan tantangan yang dialami siswa dalam menggunakan kartu domino sebagai media pembelajaran teks deskriptif di SMP 6 Wonogiri. Jenis penelitian yang digunakan adalah deskriptif kualitatif. Subjek penelitian ini adalah guru dan siswa SMP 6 Wonogiri dengan jumlah 2 guru dan 6 siswa. Penelitian ini digunakan dengan teknik wawancara dan observasi dalam pengumpulan data. Hasil penelitian ini menunjukkan bahwa penerapan pembelajaran teks deskriptif dengan menggunakan kartu domino dapat meningkatkan penguasaan kosakata siswa, antusiasme siswa dalam proses pembelajaran, dan kefasihan dalam menulis teks deskriptif. Namun demikian, terdapat beberapa kesulitan yang dihadapi siswa sebagai berikut: 1) siswa memiliki keterbatasan kosakata dan tegang. 2) Siswa kurang paham dan tidak pernah menggunakan kartu domino sebelumnya. 3) Siswa merasa kesulitan untuk memahami instruksi yang diberikan. Meskipun mengalami beberapa kesulitan, siswa merasa senang dan antusias dengan penggunaan kartu domino sebagai media pembelajaran dalam pembelajaran teks deskriptif.
\end{abstract}

Kata kunci: kartu domino, media pembelajaran, menulis teks deskriptif

\begin{abstract}
This study aims to investigate the process of teaching descriptive text using domino cards and the challenge experienced by student in using domino cards as teaching media of descriptive text at SMP 6 Wonogiri. This type of research is descriptive qualitative. The subjects of this study were teachers and students of SMP 6 Wonogiri with 2 teachers and 6 students. This study used to interview and observation techniques in data collection. The results of this study indicate that the implementation of teaching descriptive text using domino cards improved students' vocabulary mastery, student enthusiasm in the learning process, and fluency in writing descriptive text. However, there were several difficulties faced by the students as expressed as follows: 1) the students had limited vocabulary and a tense. 2) The students were unfamiliar with and never used domino cards before. 3) The students found it difficult to understand the instructions given. Although experiencing some difficulties, the students felt happy and enthusiastic about the domino cards as teaching media in learning descriptive texts.
\end{abstract}

Keywords: domino cards, teaching media, writing descriptive text

\section{INTRODUCTION}

Humans are social creatures so they have to live together or in a group. According to Garang (in Puspitasari 2017) humans as social beings are creatures that live in groups and are unable to live alone. So humans in carrying out social life require interaction with each other. Language throughout the world is very diverse. In Indonesia, the national language used is Indonesian. Then, in the international world English has been agreed as a language that must be used. According to Crystal (2001) English is a global 
language. This statement represents the meaning that English is used by various nations to communicate with nations throughout the world. In Indonesia, English as foreign language has been studied since in Elementary School. Its purpose is to make students be able to communicate well. In learning English there are important things that must be achieved, namely four macro skills. Listening, speaking, writing, and reading. Everything must be mastered so that communication between humans is very easy.

Writing is an important English skill in communication. According to Emig (1997) writing is a unique model of learning. It involves active participation of both the left and right hemisphere of the brain. Writing is a communication that allows the writer to put their feeling, creativity, and ideas. Writing can be implemented in writing paragraph, story, novel and etc. In writing skill, there are many keys that must be concerned for making a good written communication. They are spelling, punctuation, and grammar.

There are several media that can be used in teaching writing a descriptive text. One of them is domino cards. Dominoes are very useful, easy, and entertaining games to practice any set of vocabulary (Lebedova, 2011). This game can be played in pairs or in groups. Domino is a new innovation using cards for games as media used in the English learning method to facilitate learning about descriptive text. This kind of Domino games do not use dot or number in a domino card but changed by two instructions, in left side changed by picture that shows some job or occupation, and in right side written a description text about some job or occupation. To play this game, it is like playing domino as usual, but the student must match the picture and the text description.

The English teachers of SMP 6 Wonogiri must be able to choose the right technique for teaching writing a descriptive text. The medium used by the teachers were domino cards especially in teaching writing a descriptive text. Thus, the author was motivated to write a paper entitled "the use of domino cards as teaching media of writing descriptive text at SMP 6 Wonogiri" to investigate the process of teaching descriptive text using domino cards and the challenge experienced by student in using domino cards as teaching media of descriptive text at SMP 6 Wonogiri. 


\section{METHOD}

This research is a qualitative research. A qualitative research is a research that intends to understand phenomena experienced by research subjects. Some examples of the phenomena are behavior, perception, motivation, action, in the form of words and language, in a special natural context and by utilizing various natural methods (Moleong in Haris, 2010). Interview and observation were used to collect data. Interview was carried out by the researcher to explore the perspectives of both students and teachers. Observation was chosen to investigate how the situations of the classroom activities were. Observation was carried out during the teaching and learning process in the classroom. The result of observation helped the researcher to know the learning motivation by the students and it was described in notes. From these data the researcher received information about the implementation of using domino cards in teaching a descriptive text and challenges faced by the students by using domino cards as media in learning a descriptive text. To check the credibility of the data the researchers used triangulation techniques. Triangulation is important to research is carried out in order to get more accurate and reliable data. In the process of collecting data, there are often inequalities between one source and another.

\section{FINDINGS AND DISCUSSION}

\subsection{Findings}

\subsubsection{The implementation of using domino cards in teaching a descriptive text writing}

The domino cards which have competitive characteristics when played can encourage students to be active in joining the lesson. The following is the implementation of teaching writing descriptive text using domino card:

1) The teachers gave an instruction how to play the game and explain the role how to play the game.

The teachers provided instructions and explained how to play the domino cards. It can be seen that giving instructions and explaining how to play before the start of the domino card game is important because this step is the reference in the course of the domino card game. 
2) The teachers divided the students into 5 groups.

The teachers divided the students into several groups consist of 5 to 7 student. Groups are formed by students counting one to five and are grouped according to the numbers mentioned. This was done because this domino card game must be played in groups.

3) The teachers give one set dominoes to each group and the student should not show their cards to another group.

The teachers distributed a set of dominoes to each group.The students were asked not to open the cards before. Domino cards are played by sorting the descriptive text on the card with the images on the other card. And so on until the card runs out.

4) The teachers asked to each group to shuffle /mix up the dominoes and place them all facing down on the table.

The teacher asked the students to randomize the domino cards that had been distributed to each group by shuffling the card.

5) The teachers asked each group to match each picture with the meaning that provide in the domino cards.

The teacher asked the students to match the pictures on the domino cards with the description text on the other side of the domino cards. This is done again in turn by each student in the group. and if there are cards left, it means that there is something wrong between the description text and the matched image.

6) The teachers asked each student to memorize all of the vocabulary in domino cards.

The final step was that the teachers asked the students to write or create a descriptive text without looking at the pattern of the description text on the domino cards. after the student has finished making the description text in his own language, the student is asked to come forward to read what he wrote or described. 
3.1.2 Challenges experienced by the students in using domino cards in writing a descriptive text

1) Vocabulary use

There are some problems faced by the students while using domino cards in writing a descriptive text. The followings are from the students' perspectives:

Student 1:

"Ada beberapa kata yang sulit, saya tidak tahu artinya"

"There are some words that are difficult, I don't know what they mean"

From the statement given, the student was unfamiliar with the meanings of some words.

Student 2:

"beberapa kata ada yang saya tidak tahu artinya"

"Some words that $i$ don't know their meaning"

Based on this statement, the student did not understand the meaning of some words. It was difficult for the student to match the descriptive text with the existing pictures

Student 3:

"Kosakatanya banyak yang saya tidak tahu, harus mencari di kamus"

"I don't know a lot of vocabulary, I have to look up the dictionary"

From the statement, the student had limited knowledge of lots of vocabulary. It caused the student to look up the dictionary to find the meanings of the words.

Student 4:

"Kesulitan yang pertama karena kata katanya saya tidak tahu artinya, yang keduat eman satu kelompok juga tidak tahu artinya jadi tambah sulit"

" The first difficulty is because I don't know the meaning of the words, the second friends in group don't know the meaning, so it's getting more difficult"

Lack of vocabulary made the student face difficulties in using domino cards. 


\section{Student 5:}

"karena baru pertama kali ada game seperti ini dan ada kesulitan waktu mengartikan kalimatnya, karena ada kata kata yang saya tidak tahu”

"Because this is the first time there is a game like this and there are difficulties in interpreting the sentences, because there are words that I don't know"

The student had a challenge in using domino cards when the student was unfamiliar with the meaning of the words.

Student 6:

"pertama tama sulit memahami instruksi yang diberikan guru dan banyak kata kata yang baru jadi kesulitan karena tidak tahu arti kata katanya”

"It is difficult to understand the instructions given by the teacher and many new words become difficult because they do not know the meaning of the words"

The statement states that the student felt difficult because the student found new words that the the meanings were unfamiliar

2) New experience in using domino cards

Student 5:

"karena baru pertama kali ada game seperti ini dan ada kesulitan waktu mengartikan kalimatnya, karena ada kata kata yang saya tidak tahu”

"Because this is the first time there is a game like this and there are difficulties in interpreting the sentences, because there are words that I don't know"

The use of domino cards as learning media for the first time caused the student to feel confused in carrying out the learning activities.

3) Difficulty in understanding the instruction

Student 6:

"pertama tama sulit memahami instruksi yang diberikan guru dan banyak kata kata yang baru jadi kesulitan karena tidak tahu arti kata katanya” 
"It is difficult to understand the instructions given by the teacher and many new words become difficult because they do not know the meaning of the words"

The statements suggest that the difficulty in understanding the instructions given by the teachers caused the student to feel insecure in encountering the activities in the classroom.

\subsection{Discussion}

3.2.1 The implementation of using domino cards in teaching a descriptive text writing Dalle, Burhanuddin, and Usman (2018) revealed that domino cards are very effective to be used in the learning process. Rufaidah (2019) domino learning cards can be one of the learning media that can be used by the teachers to improve the students' learning achievement. Yolageldili and Arikan (2011) stated that the steps to play domino should be implemented orderly. According to the data, using domino as learning media is good for the teachers to teach writing a descriptive text. It makes the students more interested in English lesson.

Padang (2019) states that domino cards give many benefits for student. It improves students' speaking ability and makes them enjoy to study English. The teacher stated that using domino cards made the students not feel bored in learning process. It is also found that there was an increase in vocabulary mastery by the students so that they were able to write descriptive texts smoothly even though they still looked up the dictionary.

Teacher 2 referring to to Khalidiyah (2017) that the students were more enthusiastic and motivated in learning and practicing new words as well as producing the words. The teacher stated that by using domino cards the students felt enthusiastic more curious about descriptive sentences and interested in finding the meanings of words from the dictionary. Other than these, the students' understanding about domino cards improved.

The effect that the students received from the domino cards as learning media in writing a descriptive text was quite positive. Some students were helped by composing in sentences and pictures so that they increased their vocabulary. They 
were also helped by the existence of pictures that made it easier for them to make descriptive texts. It can be summarized that there will be positive effect if a learning process is conducted with attractive media so that the students feel excited to participate in the classroom.

3.2.1 Challenges experienced by the students in using domino cards in writing a descriptive text

There were some problems faced by the students while using domino cards as learning media. Almost all of the students found challenges in vocabulary.

Student 1 in line with Rabab'ah in Siregar and Nugroho (2015) stated that he had lack stock of vocabulary and difficulties in using tenses. The student had a challenge when the domino cards showed difficult words. Meanwhile,

Student 2 had difficulty in interpreting the sentences on the cards because he did not know their meaning.

Based on student 3, he/she had difficulty because his vocabulary was limited. Therefore, he was difficult to interpret the sentences. However,

Student 4, student felt difficult when there were lots of new words that he/she did not know the meaning. In line with this,

Student 5 referring to Padang (2019) stated that did not know about domino cards and never used it before. It was his/her new experience in using domino cards. Interpreting the sentences because of unfamiliarity with new words was also a problem.

Furthermore, student 6 agreeing Halim (2020) stated that the student had lack of attention to the materials given. The student felt difficult in understanding the instructions and the meaning of some words. Additionally, his/her friends in one group were also unfamiliar with meanings of the words.

There were many challenges faced by the students in using domino cards as learning media in writing a descriptive text. Almost all of the students' problem was lack of vocabulary. It relates to Rabab'ah in Siregar and Nugroho (2015) stating that students have limited stock of vocabulary and also have difficulties in understanding tenses. To sum up, the most factor the students faced in using domino cards was lack 
of vocabulary. Some students found it easy to write a descriptive text through domino cards and fun but the others did not.

\section{CLOSING}

Using domino cards in teaching a descriptive text increased students' vocabulary. Besides, the students became more enthusiastic in the teaching and learning activities, especially in writing descriptive texts the students also became smoother in writing descriptive texts.

The teacher had implemented domino cards as media properly and correctly, but the teacher still has difficulties because some students have problems with vocabulary, some students are using domino for the first time, and it is difficult to understand the instructions given by the teacher The teachers felt that the students were happier and more enthusiastic in using domino cards as media in writing a descriptive text. There were several problems faced by the students while using domino cards in writing a descriptive text. Almost all of the students had a problem of being lack of vocabulary which was one of the important things in learning English. This factor caused reduced time in learning activities so that the lessons given were sometimes not completed. However, using domino cards as media in teaching descriptive text was quite positive. The students felt excited in using domino cards and they made the students more active in the classroom activities.

\section{REFERENCES}

Oshima, A.,, \& Hogue, A. (1999). Writing Academic English. Longman.

Crystal, D. (2001). Language and Internet. Cambridge University Press.

Dalle, Ambo, Burhanuddin, and Usman, M. (2018). The Effectiveness of Domino Card Games to Improve German Language Vocabulary. Journal of Physics: Conference Series 1028(1).

Emig, J. (1997). Language and Learning. University of California.

Halim, M.L.A. (2020). Modifying Domino Cards to Increase Students' Understanding of The Use of Possessive Adjective at Junior High School.

Khalidiyah, H. (2017). The Use of Domino Game with Picture in Improving Students' Vocabulary Knowledge.

Lexy, J. Moleong. (2010). Metodologi penelitian kualitatif. 
Lebedova, M. (2011). Practicing Vocabulary Through Game-Based Activities.

Padang, R.S. (2019). Developing Domino Cards as Vocabulary Media in Learning Notice for the Seventh Grade Students at SMP Negeri 1 Sidikalang. UniversitasNegeri Medan.

Rufaidah, E. (2019). The Effect of Domino Game Learning Media on Student Learning Achievement.

Siregar, H. (2015). The Use of Single Picture As A Media To Teach Writing Descriptive Text To Seven Graders of SMP Angelus Custos II Keprabon, Surabaya. 